\title{
Watershed Scale Response to Climate Change-Yampa River Basin, Colorado
}

\section{Introduction}

General Circulation Model (GCM) simulations of future climate through 2099 project a wide range of possible scenarios (Intergovernmental Panel on Climate Change, 2007). To determine the sensitivity and potential effect of long-term climate change on the freshwater resources of the United States, the U.S. Geological Survey Global Change study, "An integrated watershed scale response to global change in selected basins across the United States" was started in 2008. The long-term goal of this national study is to provide the foundation for hydrologically based climate-change studies across the nation.

Fourteen basins for which the Precipitation Runoff Modeling System (PRMS) has been calibrated and evaluated were selected as study sites. PRMS is a deterministic, distributed-parameter watershed model developed to evaluate the effects of various combinations of precipitation, temperature, and land use on streamflow and general basin hydrology. Output from five GCMs and four emission scenarios were used to develop an ensemble of climate-change scenarios for each basin. These ensembles were simulated with the corresponding PRMS model. This fact sheet summarizes the hydrologic effect and sensitivity of the PRMS simulations to climate change for the Yampa River Basin at Steamboat Springs, Colorado (U.S. Geological Survey streamflow-gaging station 09239500; fig. 1) presented in the project summary report (Markstrom and others, 2012) and two journal articles (Hay and others, 2001; Battaglin and others, 2011).

\section{Study Area}

The Yampa River at Steamboat Springs, Colorado, is part of the Green River Basin and is an important tributary of the Colorado River. The 1,471-square-kilometer $\left(\mathrm{km}^{2}\right)$ basin ranges in elevation from 2,040 to 3,800 meters with a mean elevation of 2,674 meters. The Yampa River Basin is mountainous thus its streamflow is dependent strongly on snowmelt. The Yampa River at Steamboat Springs, Colorado was included in the Hydro-Climatic Data Network; the streamflow records prior to 1987 (when the Stagecoach Reservoir was completed) for this streamflow-gaging station are relatively "unaffected by artificial diversions, storage, or other works of man in or on the natural stream channels or in the watershed" (Slack and Landwehr, 1992). The Yampa River Basin is one of only a few river basins in Colorado where current (water years 1988-1999) and projected total water demand is less than the native supply (Colorado Water Conservation Board, 2002). Because of its importance as a source of water to the Colorado River, the U.S. Geological Survey conducted studies (Hay and others, 2006a; Hay and others, 2006b) of the effects of potential climate change on the water resources of the Yampa River Basin.
Tourism that results from abundant local recreational options is the largest source of revenue in the region (Steamboat on the Move, 2009), but agriculture also is important. Many of the recreational activities, such as fishing, whitewater boating, snowmobiling, and skiing, are dependent directly on the basins water resources. The Steamboat Ski area is located within the Yampa River Basin and has a base elevation of 2,203 meters and top elevation of 2,768 meters. The ski area typically receives more than 8 meters of snowfall, and operates from late November to early April. 


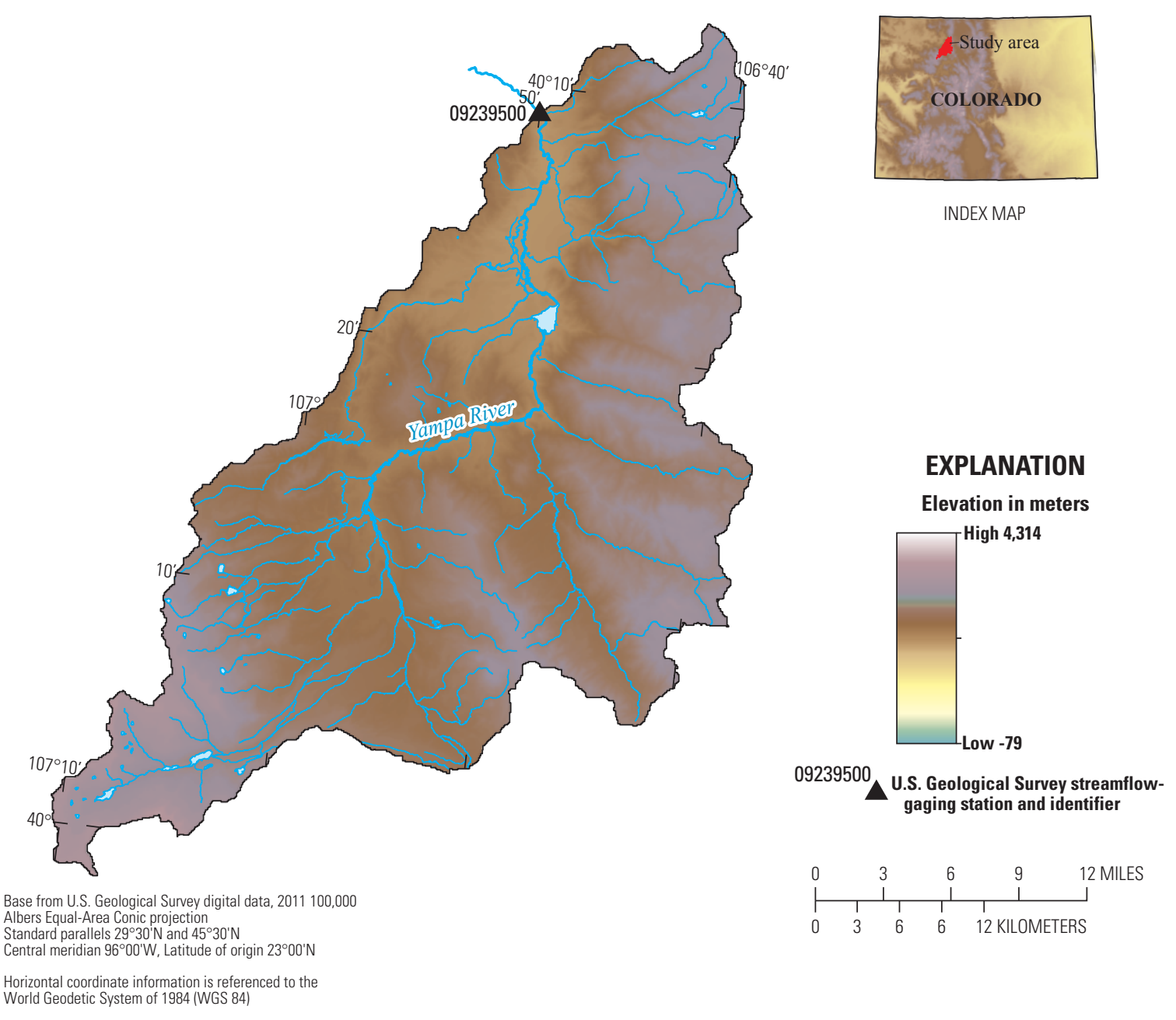

Figure 1. Precipitation Runoff Modeling System study locations, Yampa River Basin, Colorado, and location of U.S. Geological Survey streamflow-gaging station 09239500 with a drainage area of 1,471 square kilometers and elevation range from 2,040 to 3,800 meters.

\section{General Circulation Models}

Given the uncertainty in climate modeling, it is desirable to use more than one GCM to obtain a range of potential future climatic conditions. Monthly precipitation and temperature output from five GCMs was processed (table 1).

Table 1. General Circulation Model (GCM) projections used in this study.

\begin{tabular}{ll}
\hline \multicolumn{1}{c}{ GCM } & \multicolumn{1}{c}{ Center and country of origin } \\
\hline BCC-BCM2.0 & Bjerknes Centre for Climate Research, Norway \\
CSIRO-Mk3.0 & Australia's Commonwealth Scientific and Industrial Research Organization, Australia \\
CSIRO-Mk3.5 & Australia's Commonwealth Scientific and Industrial Research Organization, Australia \\
INM-CM3.0 & Institute for Numerical Mathematics, Russia \\
MIROC3.2 & National Institute for Environmental Studies, Japan \\
\hline
\end{tabular}


The GCM outputs were obtained from the World Climate Research Programme's Coupled Model Intercomparison Project phase 3 multi-model dataset archive, which was referenced in the Intergovernmental Panel on Climate Change Fourth Assessment Special Report on Emission scenarios (Intergovernmental Panel on Climate Change, 2007). For each GCM, one current (water years 1988-1999) and three future emission scenarios were used and are described in table 2.

Table 2. Climate-change emission scenarios simulated by the General Circulation Models in this study.

\begin{tabular}{ll}
\hline \multicolumn{1}{c}{ Emission scenario } & \multicolumn{1}{c}{ Description/assumptions } \\
\hline 20C3M & 20th century climate used to determine baseline (1989-1999) conditions \\
A1B & $\begin{array}{c}\text { Rapid economic growth, a global population that peaks in mid-21st century and rapid introduction of new and } \\
\text { more efficient technologies with a balanced emphasis on all energy sources } \\
\text { Convergent world, with the same global population as Emission scenario A1B, but with more rapid changes in } \\
\text { economic structures toward a service and information economy that is more ecologically friendly }\end{array}$ \\
A2 & Heterogeneous world with high population growth, slow economic development, and slow technological change \\
\hline
\end{tabular}

Climate-change fields were derived by calculating the change in climate from current (water years 1988-1999) to future conditions simulated by each GCM. The 20C3M simulation for water years 1988-1999 was used to represent current climatic conditions. This 12-year period of record was chosen based on the overlap of the available historical records from the 14 basins included in the national study. Climate change fields (percentage changes in precipitation and degree changes in temperature) were computed for 12-year moving window periods (from 2001-2099) using the 20C3M (1988-1999) and the A1B, B1, and A2 emission scenarios. A 12-year moving window, starting in 2001 and ending in 2099, results in 1,320 future scenarios $[(88,12$-year climatologies, 1 per year starting with 2001-2012 and ending with 2088-2099) x (3 emission scenarios) x (5 GCMs)].

Climate-change scenarios were generated for PRMS by modifying PRMS precipitation and temperature inputs with the mean monthly climate change fields derived from the GCMs, resulting in 1,320 PRMS-input files. Table 3 shows the change (slope) and adjusted $\mathrm{R}^{2}(\operatorname{adj} R 2)$ for the least squares fit to the trend line for selected output variables from the PRMS projections. The slope indicates the change in the selected variable by year. The adjusted $\mathrm{R}^{2}$ value gives an indication of the variability in the central tendency of the trend line.

Figure 2 shows a summary of the projected range in 11-year moving mean daily values of maximum temperature (fig. $2 A$ ), minimum temperature (fig. $2 B$ ), and precipitation (fig. $2 C$ ) by emission scenario. The first year of each 12-year simulation was used as PRMS initialization and is not included in the results. The three solid-colored lines indicate the 11-year moving mean values (x-axis indicates center of 11-year window) for the three future emission scenarios (central tendency of the five GCMs for each emission scenario). The projected range shown for each emission scenario indicates the range of potential future climatic conditions simulated by the 5 GCMs. All GCM simulations project steady increases in maximum and minimum temperature (table 3), with uncertainties associated with these GCM projections increasing with time. Both maximum and minimum temperatures show the smallest projected changes for the B1 emission scenario. Projections of mean annual precipitation for the Yampa River Basin are highly variable, with a slight positive trend in the A1B scenario (table 3). The wide range in the precipitation projections indicates a large amount of uncertainty.

\section{Results}

PRMS simulates spatially distributed streamflow, components of flow (surface, subsurface, and groundwater), snowpack conditions, and many other hydrologic components of interest. Figure 3 shows the projected range in 11-year moving mean daily values of streamflow by emission scenario. The lines of central tendencies of the PRMS simulations for each emission scenario all project a decrease in mean annual streamflow by the end of the 21 st century (table 3 ), though the uncertainties associated with these streamflow projections are large.

Projected changes in streamflow can be examined on a monthly basis to determine if the timing of peak runoff is expected to change (fig. 4). The solid-red lines show PRMSsimulated mean monthly baseline conditions (1989-1999) for streamflow, and the boxplots represent the range in the mean monthly outputs for the five GCMs and three emission scenarios for 2030 (green, 2025-2035), 2060 (tan, 2055-2065) and 2090 (green, 2085-2095). The boxplots indicate that not much change is expected during the late summer and early winter months (August-February). However, by the end of the 21st century, streamflow increases are projected in March, and more substantially in April, followed by a substantial decrease in June with smaller decreases in July. By as early as 2030, peak timing of streamflow is projected to shift from June to May.

Analysis of other states of interest, produced by PRMS, can indicate areas of the water balance most susceptible to changes in climate. Changes in the development of snowpack and the timing of snowmelt are important in the Yampa River Basin from a water-supply standpoint, and because of potential effects on recreational activities in the area. For example, figure 5 shows summaries of the basin mean annual snow-covered area. Consistent with the projected increase in temperatures (figs. $2 \mathrm{~A}$ and $2 B$ ), a steady decrease in mean annual snow-covered area is projected in the basin (table 3 ), with uncertainty around the projected decreases increasing with time (fig. 5). The projected decreases in mean annual snow-covered area vary considerably for the three emission scenarios and the five GCMs.

Projections of snow-covered area on a mean monthly basis (fig. 6) show large decreases from October through December and from March through June. Minimal changes in mean monthly snow-covered area are projected during January through February. In Colorado, the month of March traditionally 

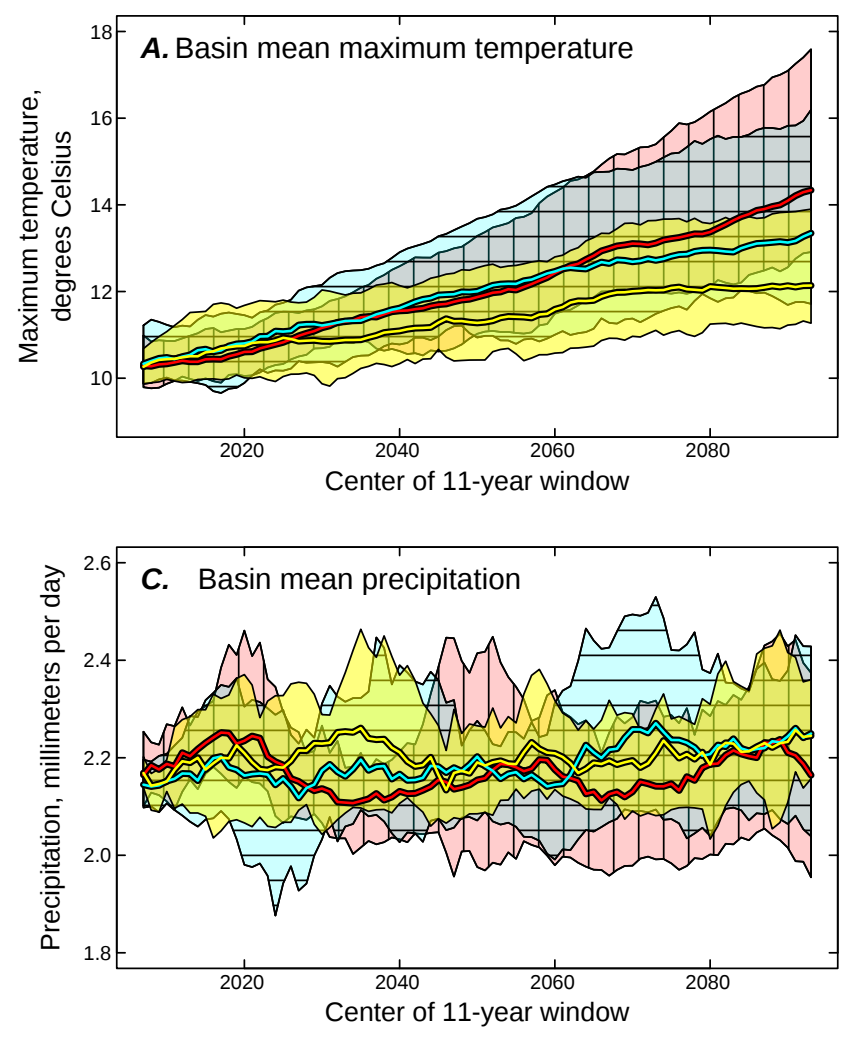

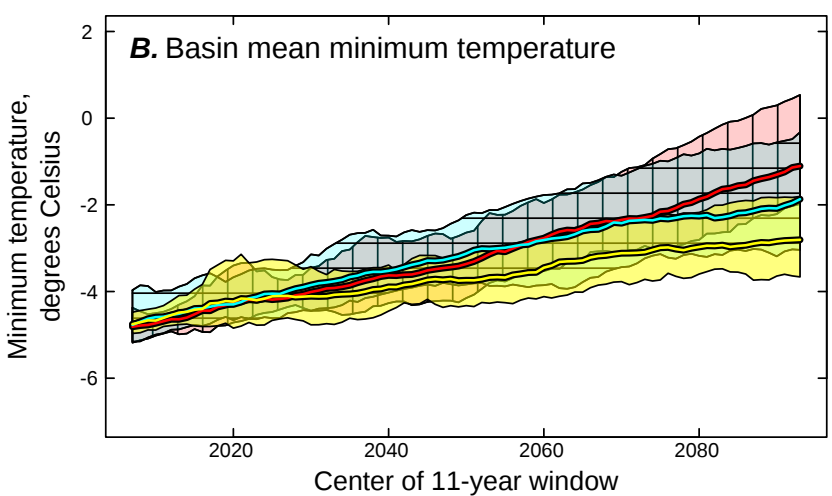

EXPLANATION

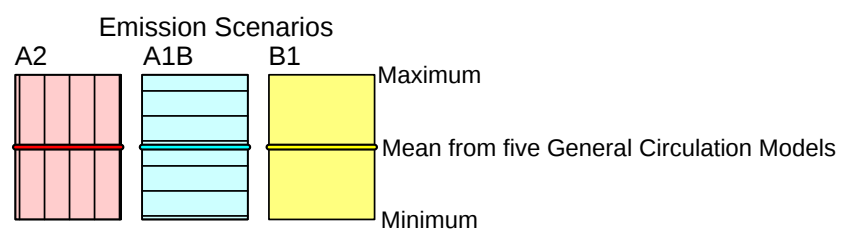

Figure 2. Projected range in 11-year moving mean daily values of $(A)$ maximum temperature, $(B)$ minimum temperature, and $(C)$ precipitation by emission scenario.

Table 3. Projected change by year (slope) and adjusted $R^{2}$ (adjR2) based on the central tendencies of the five General Circulation Models for the three carbon emission scenarios for selected Precipitation Runoff Modeling System (PRMS)output variables.

[Blue indicates a significant negative trend and yellow indicates a significant positive trend $(\mathrm{p}<0.05)$ accounting for lag-1 autocorrelation]

\begin{tabular}{|c|c|c|c|c|c|c|}
\hline \multirow{2}{*}{ PRMS output variable } & \multicolumn{2}{|c|}{$\begin{array}{c}\text { Emission scenario } \\
\text { A1B }\end{array}$} & \multicolumn{2}{|c|}{$\begin{array}{c}\text { Emission scenario } \\
\text { A2 }\end{array}$} & \multicolumn{2}{|c|}{$\begin{array}{c}\text { Emission scenario } \\
\text { B1 }\end{array}$} \\
\hline & slope & adjR2 & slope & adjR2 & slope & $\operatorname{adjR2}$ \\
\hline Maximum temperature in degrees Celsius & 0.035 & 0.99 & 0.047 & 0.99 & 0.023 & 0.97 \\
\hline Minimum temperature in degrees Celsius & 0.033 & 0.99 & 0.042 & 0.99 & 0.022 & 0.98 \\
\hline Precipitation in millimeters per day & 0.0011 & 0.56 & -0.0001 & -0.01 & 0.0004 & 0.10 \\
\hline Streamflow in cubic meters per second & -0.0205 & 0.77 & -0.0415 & 0.89 & -0.0211 & 0.67 \\
\hline Snow-covered area in percent per day & -0.10 & 0.98 & -0.16 & 0.98 & -0.08 & 0.94 \\
\hline
\end{tabular}

has the best ski conditions and often the most skier visits (Roark Kiklevich, oral commun., 2010). Basin mean annual changes in snow-covered area for only the month of March are shown in figure 7. Projected decreases for March only are of a similar magnitude as those shown for the entire year (fig. 5).

Presumably, ski area locations are picked at least in part because of a tendency to receive and/or keep snowpack. The effect of location within the basin can be examined by comparing basin mean simulations of snow-covered area with simulations from the individual hydrologic response unit(s) (HRU) that represent the ski area in the PRMS model. Simulations of snow-covered area for March for an HRU that covers the base portion of Steamboat ski area (and surrounding areas) show small projected decreases for the B1 scenario (yellow) (fig. 8), but more substantial decreases for the A1B scenario (blue) and A2 scenario (red) with a wide range of projections after 2050.

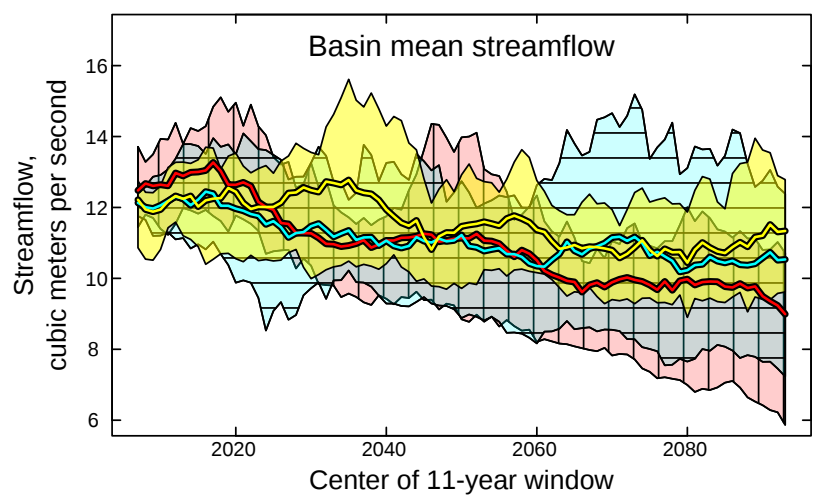

Figure 3. Projected range in 11-year moving mean daily values of streamflow by emission scenario. 


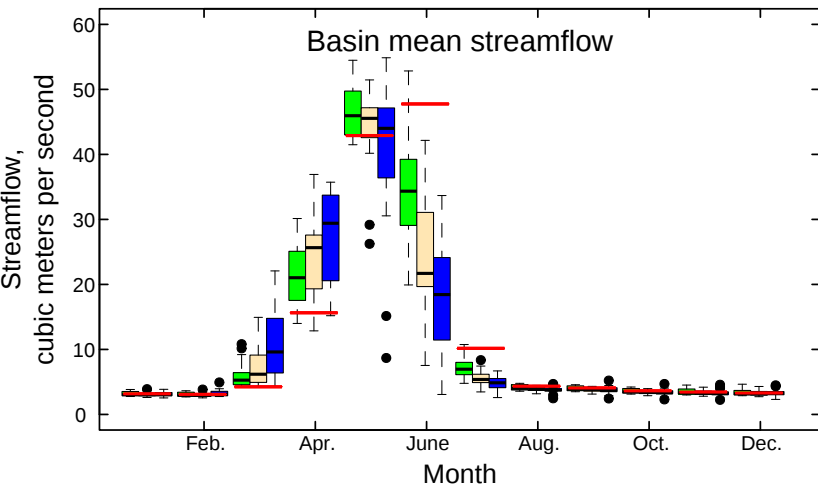

Baseline Conditions (1989-1999)
EXPLANATION

\begin{tabular}{ccc}
2030 & 2060 & 2090 \\
$(2025-2035)$ & $(2055-2065)$ & $(2085-2095)$ \\
\hline
\end{tabular}

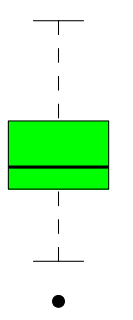

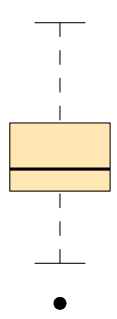

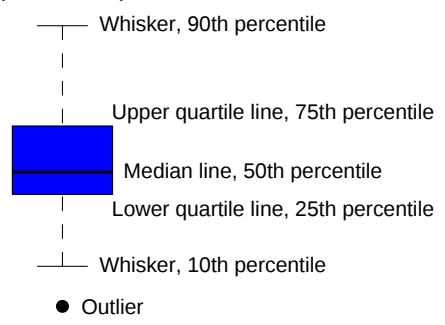

Figure 4. Mean daily streamflow values by month for baseline conditions and projected range (2030, 2060, and 2090) using the five General Circulation Models and three emission scenarios.

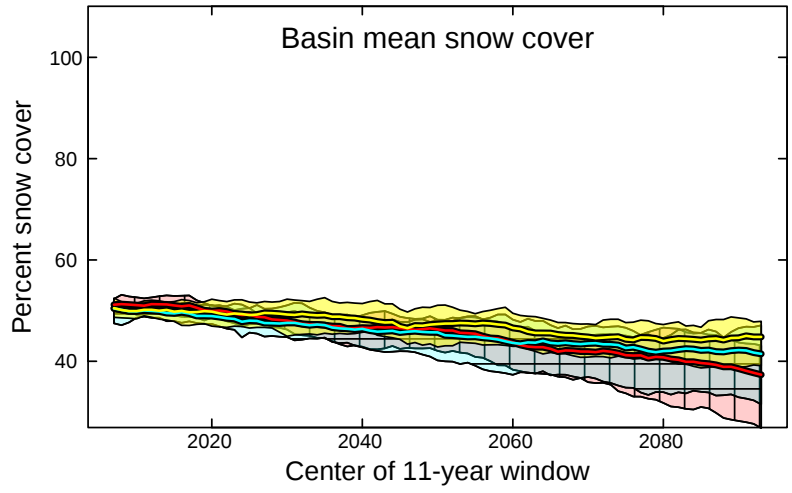

Figure 5. Projected range in 11-year moving mean daily values of snow-covered area by emission scenario.

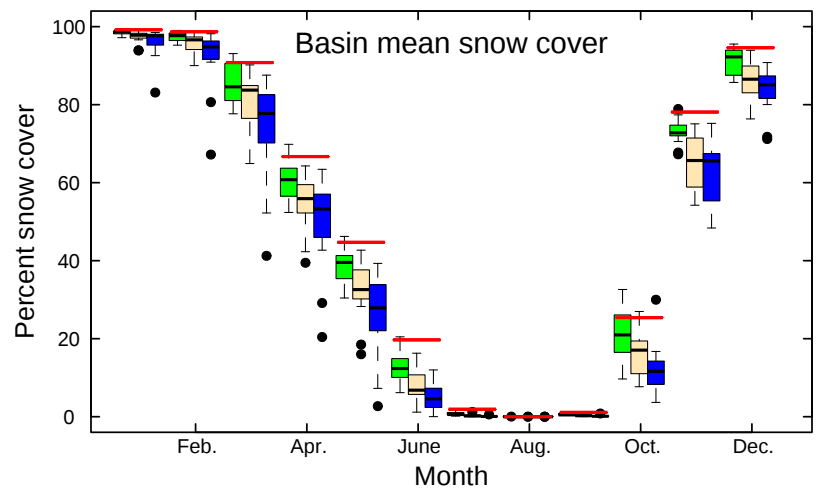

Figure 6. Mean daily snow-covered area values by month for baseline conditions and projected range (2030, 2060, and 2090) using the five General Circulation Models and three emission scenarios.

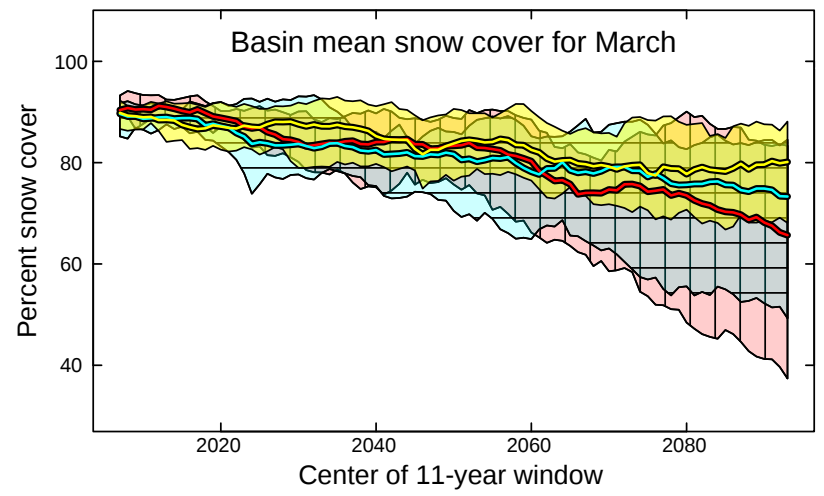

Figure 7. Basin mean annual changes in snow-covered area for the month of March.

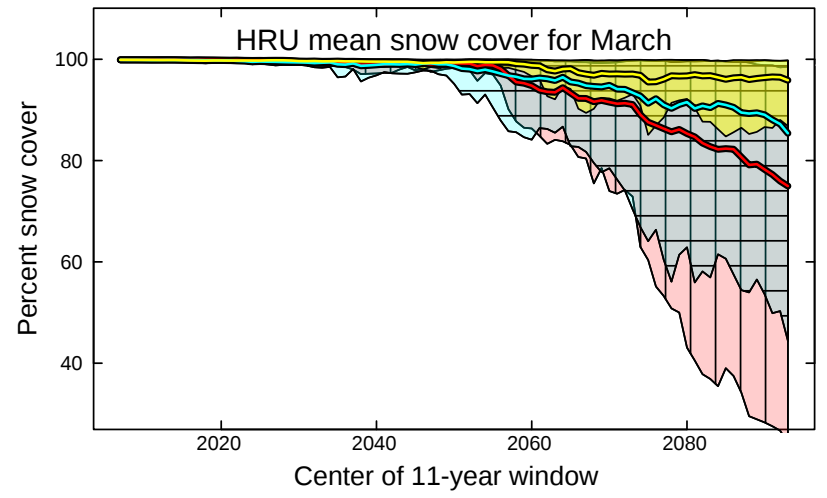

Figure 8. Hydrologic Response Unit (HRU) mean annual changes in snow-covered area for the month of March. 


\section{Conclusion and Discussion}

Streamflow in the Yampa River Basin is under increasing demand from water users and energy companies in the southwestern United States, and recreationalists within the basin. Potential changes in streamflow resulting from future changes in climate may add to the stress that this basin will experience as there also are projected increases in domestic and industrial water use (Colorado Water Conservation Board, 2006). The effects of climate change in the Yampa River Basin may alter both the quantity and timing of streamflow and have the potential to change the conditions that support recreational activities such as skiing. The scientific techniques described in the fact sheet can be augmented with other techniques in developing the science needed to address the effects of future changes in climate on streamflow and snowpack dynamics in mountainous regions.

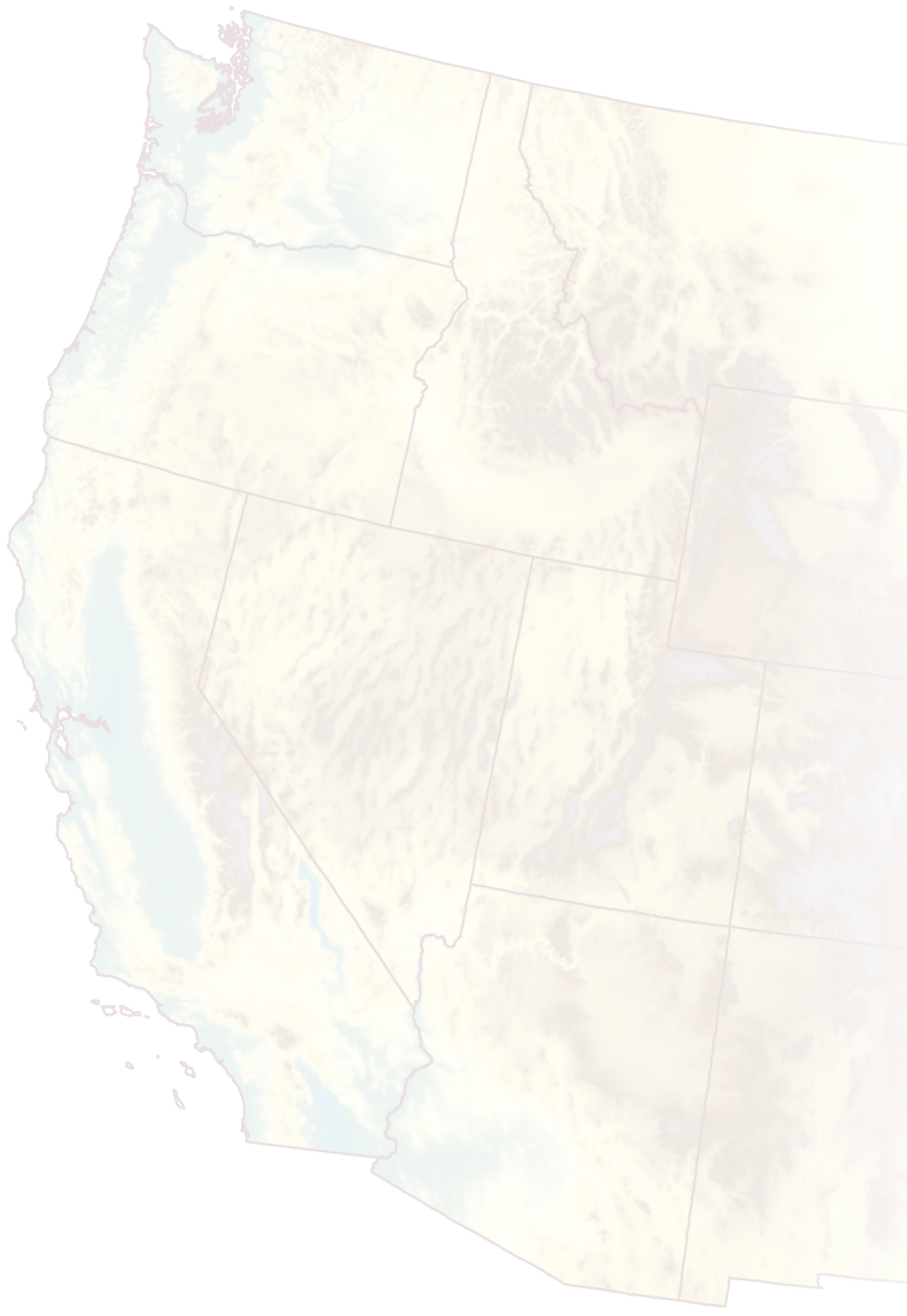

\section{By Lauren E. Hay, William A. Battaglin, and} Steven L. Markstrom

For more information visit the following Web sites: http://wwwbrr.cr.usgs.gov/projects/SW_MoWS/

http://co.water.usgs.gov/

http://www.usgs.gov/climate_landuse/

\section{Selected References}

Battaglin, W., Hay, L., and Markstrom, S.L., 2011, Simulating the potential effects of climate change in two Colorado basins and at two Colorado Ski areas: Earth Interactions, v. 15, 23 p.

Colorado Water Conservation Board, 2002, Yampa/White River basin water use, growth \& water demand projections. Colorado Water Conservation Board Fact Sheet, 5 p., available online at http://cwcbweblink.state.co.us/WebLink/0/ doc/118984/Page1 .aspx? searchid $=4 f b 0 b 598-d 605-4 b 25$ b2e2-9168d27fd94a.

Colorado Water Conservation Board, 2006, Statewide water supply initiative fact sheet: Yampa/White/Green basin. Colorado Water Conservation Board Fact Sheet, 2 p., available online at http://cwcbweblink.state.co.us/weblink/docview. aspx?id $=119003 \&$ search handle $=12637$.

Hay, L.E., Clark, M.P., Pagowski, Mariusz, Leavesley, G.H., and Gutowski, W.J., Jr., 2006a, One-way coupling of an atmospheric and a hydrologic model in Colorado: Journal of Hydrometeorology, v. 7, no. 4, p. 569-589.

Hay, L.E., Leavesley, G.H., Clark, M.P., Markstrom, S.L., Viger, R.J., and Umemoto, Makiko, 2006b, Step-wise, multipleobjective calibration of a hydrologic model for a snowmeltdominated basin: Journal of American Water Resources, p. $877-890$.

Hay, L.E., Markstrom, S.L., and Ward-Garrison, C.D., 2011, Watershed-scale response to climate change through the twenty-first century for selected basins across the United States, Earth Interactions, v. 15, 37 p.

Intergovernmental Panel on Climate Change, 2007, Summary for policymakers, in Climate change 2007-The physical science basis, Contributions of Working Group 1 to the Fourth Assessment Report of the Intergovernmental Panel on Climate Change: Cambridge and New York, Cambridge University Press, $18 \mathrm{p}$.

Markstrom, S.L., Hay, L.E., Ward-Garrison, C.D., Risley, J.C., Battaglin, W.A., Bjerklie, D.M., Chase, K.J., Christiansen, D.E., Dudley, R.W., Hunt, R.J., Koczot, K.M., Mastin, M.C., Regan, R.S., Viger, R.J., Vining, K.C., and Walker, J.F., 2012, An integrated watershed scale response to climate change for selected basins across the United States: U.S. Geological Survey Scientific Investigations Report 2011-5077, 142 p.

Slack, J.R., and Landwehr, J.M., 1992, Hydro-climatic data network (HCDN); a U.S. Geological Survey streamflow data set for the United States for the study of climatic variations, 1874-1988: U.S. Geological Survey Open-File Report 92-129, $193 \mathrm{p}$.

Steamboat on the Move, 2009, 2008: Business and the economy, accessed January, 2009, http://www.steamboatonthemove.com/. 